\title{
Realities of National and International Trade Regulations and Policies
}

\author{
P. Marcus W. De Freitas \\ Minister of Trade, Industry \& Agriculture, St. Vincent and The Grenadines
}

This paper deals with the "Realities of National and International Trade Regulations and Policies" as they affect trade in primary agricultural and horticultural products. I will not be able to cover all of the issues (controversial at times) that surround such a complex topic, but will certainly attempt to highlight some of the areas that adversely affect us as small developing countries in the Caribbean. Our efforts at agricultural and national development will be discussed with particular reference to the problems experienced in marketing our products in the United States and other developed countries.

In St. Vincent and The Grenadines, the national development policies in the agricultural sector stress the need for the production of high-quality crops, whether bananas, rootcrops, fruits, vegetables, or exotic plants, and flowers. Our plans and programs are directed towards this goal,. notwithstanding the limited financial, material, and technical resources with which we work. The present efforts, therefore, strive to be consistent with the needs and requirements of the sophisticated markets of the United States and the rest of the international community.

With the assistance of the United States Agency for International Development (USAID) and the USDA, St. Vincent and The Grenadines conducted a survey in 1986-87 that has demonstrated in no uncertain terms the nonexistence of dangerous fruit flies in this country. This has confirmed St. Vincent and The Grenadines' entitlement to certification as fruit-fly free; notification of which was given. This program has been especially important to St. Vincent and The Grenadines in view of the fact that it fits neatly into the country's overall pest eradication program in the agricultural sector and supports our attempts at diversification of our agricultural base. The production of fruits, vegetables, exotic plants, and flowers is expected to play a vital role once the market for these products are secured. Fruit fly-free certification will greatly enhance the export opportunities to the United States and other markets.

We readily recognize and understand the importance of protecting national and international agriculture from pests. In the same way that countries have a right to protect their borders from an invasion by pests, so too, they must have an obligation not to export such to any other country. Efforts to reduce the incidence of pests are to be applauded. However, the reality of our experience is that trade regulations and policies are administered through the application of phytosanitary and other regulations in such away as to hinder rather than promote trade flows from the Caribbean and other developing countries to the markets of the developed countries. This is due in part to lack of information by the administrators, and in part to lobbying pressures from vested interests in the importing countries. Given this situation, there is need for greater empathy with the development efforts of the Caribbean and other developing countries by those who are charged with trade administration.

The requirements imposed on agricultural exports are manipulated and effectively used as weapons against trade development activities. This is exemplified in one instance where fumigation requirements against nonexistent fruit flies resulted in increased costs and a negative effect on quality. This has hampered efforts at market penetration, particularly in the special niches where we had very strong potential.

The situation is further compounded where unscrupulous firms and individuals in the developed countries have sold and continue to sell dangerous chemicals and pesticides to the Caribbean, products that have been banned in exporting countries because of their ill effects on human health and the environment. The sole purpose of these profiteers is to drain as much as possible of the meager resources from these countries, while putting in jeopardy the survival of Third World people.

\section{Food security}

The question of food security in the world today takes on an added dimension in light of the plight of some countries in Africa and other parts of the Third World. Food production is essential. However, modem transportation systems no longer make it necessary to produce locally all of the food required for consumption. If production is concentrated in countries that are particularly suited to produce a crop, and fair exchange can take place, then there is a linkage effect throughout the international economy, with a positive impact on employment through stimulation of activities in the transportation sector, such as shipping, trucking, etc., as well as in other services. It is indeed important that any factors affecting food security be dealt with effectively.

Policies in St. Vincent and The Grenadines toward basic sufficiency in food and toward the export of high-quality, disease- and pest-free agricultural products are structured within the context outlined above. They fall within the framework of the national laws and regulations governing plant and animal quarantine and pesticide use and management. These measures are designed to ensure national food security, in the sense of production protection, as well as to contribute to international trade. 
St. Vincent and The Grenadines sees itself as being obliged to honor its commitment to the wider international community with regard to the application of effective methods of pest control and eradication, as well as proper use of chemicals, to ensure environmental protection. Thus, the laws and regulations are set up as an integral part of the wider international effort at eliminating any threat to the overall world security of food supplies. The international aspect is being stressed here in recognition of the interrelatedness and interdependence of all countries within a total global system. This again raises the issue that, every so often, the national policies and trade regulations applied in developed countries (and, in some cases, developing countries) are effectively used as nontariff barriers to trade, thus making it almost impossible for the products of producing countries to enter these markets.

The economics of most developing countries are agro-based. They depend heavily on agricultural exports for foreign exchange earnings to enable them to import the necessary inputs for agricultural development, raw materials, machinery, and equipment needed for industrial and infrastructural development. Therefore, on one hand, to assure world food supplies the application of preventive and control measures is necessary, but, on the other hand, policies and regulations involved can constitute a barrier to trade in those products considered so vital to the economic advancement of the developing countries.

These dual roles of trade regulations must not be viewed as being antagonistic to each other. In fact, the apparent contradiction disappears when the advances of science and technology, especially in the sphere of communications, are taken into consideration. In other words, protection of production as described here need not become a barrier to trade. In all spheres of economic life, production, trade, communication, etc., science and technology has demonstrated that an adequate food supply at the international level can be guaranteed, once the necessary mechanisms are put in place and once the political will for cooperation and sharing among nations exists.

\section{Trade and development-the effect of non-tariff barriers}

Agricultural production based on a country's productive capabilities can greatly increase outputs and trade flow among countries because of the advances in science and technology referred to above. The world is but a small place and, in a matter of hours, fresh fruit, vegetables, and flowers, etc., from any part of the world can be on the tables of consumers in another. In this way, it will be possible to increase trade, raise incomes, improve employment opportunities, and, overall, improve the performance of weak, open economies such as ours in the Caribbean.

As has been indicated, many of the Caribbean economies are agro-based. While it is necessary to be aware of the importance of creating a vibrant manufacturing sector, it is also evident that the development of this sector is contingent on the ability to exploit fully the launching pad, our agricultural sector, through rational and optimum use of the limited land resources and our labor force. Labor is certainly not limiting in the Caribbean.

National trade regulations and policies are being manipulated and abused in such a way so as to create distortions in international trade. The countries that suffer most as a result of these measures are ultimately the small developing countries, where the economic base is not as diversified as other countries. Thus, our dependence on the markets of the industrialized world for the short, medium, and indeed the long term is vital for our economic survival.

Within the past decade, Caribbean economies have suffered tremendously from imported inflation, balance of payments problems, high rates of unemployment, etc. The financial difficulties of our countries since 1980, on their external accounts, have increased on a dramatic scale, with a majority having to make sharp cuts in imports as a result of declining export earnings, lower inflows of capital, and substantially higher interest payments on foreign debts.

So far in this decade, primary commodity exports have hardly been an engine of real development and growth. Rather, the little foreign exchange earned from such exports has become, for many of our countries, merely a means for keeping up interest payments to foreign banks and other creditors. In such a situation, it is difficult to see how more than a few developing countries would be able to accumulate foreign exchange reserves and build up their own domestic capital markets on a scale sufficient to allow the required level of development from our people to be achieved.

It is well-recognized and accepted that trade stimulates economic growth. Through trade, we are able to obtain the goods and services that, because of the specific situation at a particular stage of development, we are not able to produce. Through trade, we can distribute the fruits of scientific and technological progress; through trade, small developing countries such as ours in the Caribbean can acquire the hard currency that we need to finance our developmental programs. These factors are stated primarily to substantiate and to give legitimacy to our call on the United States and other developed market economies to be more flexible in their trade policies, so that our products may be afforded the opportunity to establish themselves in these markets.

Too often, the non-tariff trade regulations are riddled with conditions that are extremely difficult to meet. Cumbersome customs procedures, administrative practices, health and sanitary regulations, quality standards, packaging and labeling requirements, import quotas, and subsidies to domestic agriculture all contribute in varying degrees to the distortion and prevention of free flow of trade at the international level.

One contentious area related to these non-tariff barriers to trade in primary commodities are the subsidies given by governments to protect domestic producers. This refers specifically to agricultural production for export in the developed countries. These barriers are generally an integral part of wider income-support arrangements for their farm populations. In 1985, the cost of agricultural support in the United States, Japan, and the EEC was approaching a total of some US $\$ 50$ billion a year. Though such support has been generally successful in maintaining real incomes in the farm sector, such policies have tended to create surpluses that can be and are disposed of cheaply in our countries. This dumping of agro-based products can be analyzed from two standpoints. On one hand, it could mean cheaper imports for our countries, thus reducing the amount of our food import bill. However, on the other hand, it threatens our potential productive capacity in that it stifles local production when allied to trade difficulties or obstacles.

Due to resource limitations and small size, it is not possible to achieve economies of large-scale production. Furthermore, artificially low prices created by support schemes mean that produce of the region may not be price-competitive with respect to imported goods and products with which they may compete, both in home as well as export markets. Hence, from a strict economic standpoint, it may seem more viable and rational to import than to produce. The result is that the development thrusts can be severely handicapped and more and more of a reduced quantity of foreign exchange earnings goes back abroad as payment for our food bill, until the time comes when there is no foreign exchange to pay for the imported goods. In the meantime, local production has been severely affected.

In the United States, the cost of agricultural support programs is coming under increasing scrutiny. While this may be arising purely within the context of federal budgetary problems, it will be a determining factor that can indirectly have an impact on our development efforts. The need is now great for a reassessment of the rationale of such income-support schemes in the developed countries and for devising new policies on a sounder basis, policies that are designed to create a positive impact on the trade and development prospects of the Caribbean and other developing countries.

\section{The Caribbean Basin Initiative (CBI)}

The Caribbean Basin Initiative (CBI) approaches its 4th year of operation, but the results have left much to be desired. Although it may be a bit early to cast final judgment on the initiative, one can examine its evolution, trends, and patterns over the past 3 years to arrive at a partial evaluation of its performance. (Given the importance of concepts conveyed by names, it may be necessary to consider redesignation of the program, since a basin, in the Caribbean, 
refers to a receptacle for waste. The term Caribbean Countries Initiative would be far more appropriate. This has been already suggested in another forum.) (Refer to proceedings of CBI Congressional hearing on the CBI, Barbados, 19 Sept. 1987, where this recommendation was made by me.)

The CBI is particularly important considering that one of its pillars is in the area of trade flows to the United States from the Caribbean area. Our experience over the past 3 years has demonstrated that the CBI has not lived up to expectations and has not come to grips with the needs and requirements of Caribbean societies. Perhaps the recent attempts at amending the original plan is a signal that, somewhere in Washington, D. C., a more sober and objective assessment of Caribbean economic and social reality is being carried out. This will indeed be a most welcome development.

$\mathrm{CBI}$, as well as any other special assistance programs, must go beyond the limits of aid, investments, and trade. True, these pillars must be strengthened and made to function if the initial objectives are to be achieved; however, added emphasis must be placed on setting up the appropriate structures and framework to forge closer contacts between the United States and Caribbean organizations and citizens. This must not be seen only as a move to extend cultural contacts, but must be viewed from a short-term and, more so, as a long-term economic strategy. There is no better way to familiarize oneself with the needs and requirements of people than through person-to-person contact.

In a paper presented in Sept. 1987 to a Congressional hearing in Barbados, certain areas of cooperation that could be exploited within the framework of special assistance programs were identified. Other mechanisms outside of such a program were also suggested. A quick recapitulation of some of the points mentioned (a brief critique of the Caribbean Basin Initiative framework; Marcus De Freitas) might be in order here.

First of all, programs can be formulated to encourage farmer exchange visits: In this way, U.S. farmers and the farming lobby can be given a first-hand view of our farming activities. They would be made aware that our level of production and export in the $\mathrm{Ca}$ ribbean is but a dot in the ocean of U.S. imports, and can in no way endanger their privileged positions on the U.S. market. Second, youth exchange programs can also be done within the context of what was referred to as "Forward Marketing through Youth Exchange and Cooperation". These programs could help American youth to be able to enjoy a holiday in the beautiful Caribbean and savor the exotic fruits and vegetables and develop the needed empathy and understanding on the part of trade administrators, referred to earlier.

Many of our fruits, vegetables, and root crops are of the highest nutritional value, and we have been able to maintain their quality and standards due to our low incidence of pests and disease, minimal application of chemicals, and the development of more diseaseresistant cultivars. American visitors on exchange programs can serve initially as ambassadors to their country, to attest to the fact that we are potentially capable of supplying the U.S. market with quality products. They must also be seen in the longer term as the tourists whom these countries will be wooing in the future.

There is a need for us also to create mechanisms to accommodate exchange programs for customs, administrative, and trade officials. Through this effort, our customs and trade officials can be updated on the requirements, standards, trade, and administrative procedures of the U.S. Customs and the USDA. In addition, U.S. officials who now have little knowledge of the quality and standards of Caribbean exotic produce will be able to acquire valuable information. This will help to reduce, if not eliminate, their readiness to issue condemnation certificates to importers who seek them when conditions on the market are less than optimal and use these as reasons for not meeting their obligations to Caribbean suppliers.

In agrarian economies, such as most of those in the Caribbean, the input and dedication of thousands of small farmers who cultivate the limited arable land that we possess must be commended. The benefits of assistance programs ought to be shared among these hardworking people through opportunities to have access to markets for their products at fair prices. In St. Vincent and The Grenadines, our present program of land reform is consistent with the needs of our farmers. This program is well within the framework of our overall diversification and intensification programs. We hope that external markets will be accessible through special arrangements, such as an amended U.S. program for the Caribbean to promote trade, supported by aid as required; similar initiatives from other countries would help in this respect.

\section{A national program for improved production}

The government of St. Vincent and The Grenadines has acquired (with proper compensation) idle and underused lands that, along with state-owned estates, will be subdivided and placed in the hands of small farmers. Our agricultural diversification, intensification, and development plan is geared to promote economic development in the rural areas. The plans are indeed ambitious and constitute a challenge to our government, bearing in mind our limited resources. However, our efforts would be futile if and when our production increases-the necessary markets are not in place for the effective marketing of our products.

\section{Fair trade}

Farmers of our countries who produce these agricultural commodities and exporters who seek markets for these are the ones whose businesses are exposed to all the risks and adverse elements that threaten our economic stability. Prevailing weather conditions, world commodity prices, and the availability of markets all influence the final output of total agricultural production in any country. Similarly, the chronic problems of air transport and the unreliability of distributors and other related factors impinge on the performance of exporters of these commodities.

There is need for fairer terms of trade between the developed and developing countries. Importers and distributors in the marketplace often claim that they are taking risks in putting up capital to enable the importation of products. (However, it should also be recognized that condemnation certificates on shipments are also too readily available to these importers, as mentioned earlier.) What they do not say, however, is that they are recipients of what may be described as interest risk-free loans from producers in the developing countries. Farmers and exporters take the risks during production, harvesting, shipping, and in the market. The distributor takes no such risk since a commission for selling, shipping, handling, etc., is received regardless of the final price. Often, the exporter receives only a bill for further costs, rather than any funds. The irony here is that the resource-starved small countries are propping up the resource-rich countries, rather than the reverse. Of course, there are some firms in the developed markets that work closely with producers in the developing countries, sharing part of the risk, to whom this does not apply. These should be complimented and encouraged. But, as a general rule, too many distributors are engaged in exploitative practices rather than being true partners in development.

New initiatives should address themselves to questions of an agricultural nature. One of the major limitations of present initiatives is that, in plans designed to lend assistance to predominantly agrarian economies, provisions are often not made in the initial stages for developing strategies designed to ensure support to the agricultural sector. Agriculture is frequently tagged on as an afterthought or, more appropriately, a footnote.

\section{CONCLUSION}

In colloquia such as these, there is a need for us to spell out, quite clearly, the interrelation among the obstacles that confront us in our developmental efforts and the trade policies and regulations of our traditional friends that indirectly hinder these efforts. It is clear that initiatives such as those that give rise to the present CBI, or CARIBCAN, or any other ones, can be beneficial to us, but additional mechanisms that would allow us to exploit fully the arrangements need to be established. If acceptable objectives are to be achieved, non-tariff trade regulations must be streamlined to allow for greater access of our products to external markets and fairer terms of trade, There must be a greater political will by the decision-makers and greater understanding and empathy by those 
responsible for administration and execution of policies to make Caribbean economic development a priority area.

Caribbean countries did not choose to be underdeveloped countries. Objective historical factors have given that status to us. Since political independence, we have begun our long uphill battle toward genuine economic independence, but the task is far from being completed. Our northern and economically powerful allies on both sides of the Atlantic have a moral obligation to contribute meaningfully to this process. This has been evidenced in some ways to date. The assistance of the U.S. government through the USDA and USAID in the fruit fly program, now successfully having led to our certification as a fruit fly-free country, is a case in point. St. Vincent and The Grenadines is grateful to those concerned for programs such as these, which can lead to greater trade and reliance on our own resources rather than dependence on aid. We now hope that further assistance will be forthcoming to ensure that the needed infrastructure can be put in place to allow us to take advantage of the new opportunities that this certification now affords us.

\title{
The Role of Foreign Assistance Programs in the Development of Exportable Horticultural Crops
}

\author{
Howard L. Steele \\ Office of International Cooperation and Development, United States Department of Agriculture, \\ Washington, DC 20523
}

It is from experiences during 8 years of working as a project manager in various United States Agency for International Development (USAID) Missions overseas, principally in Latin American countries, and since 1984 within the Latin American and Caribbean Bureau of USAID in Washington, D.C. that these remarks are made. I have worked with various indigenous groups in Guatemala, Bolivia, Honduras, and Belize as they attempted to diversify their agricultural production base. That diversification usually, but not always, means moving from production for export of traditional commodities, such as sugar, bananas, and coffee, to high-value horticultural crops, such as temperate and tropical fruits and vegetables.

Most of this activity has been promoted by host country governments, USAID missions, and other bilateral and multinational organizations because of the realization that world supplies and prices for many of the traditional export commodities had become problematic. Over supplies of sugar, coffee, and bananas, and chronic softening of world prices coupled with growing debt burdens and a dearth of foreign exchange reserves, were catalytic in leading developing country leaders to want to diversify their agricultural production/marketing bases. In the Americas, the movement accelerated rapidly with passage of the Caribbean Basin Economic Recovery Act (U.S. Congress, 1983) in Aug. 1983.

\section{THE CARIBBEAN BASIN INITIATIVE (CBI)}

The Caribbean Basin Economic Recovery Act established a oneway free trade proposal between the United States and some 27 developing countries in Central America and the Caribbean islands (Table 1). The legislation was in response to bipartisan concern in the United States, also expressed in Mexico, Canada, Colombia, and Venezuela, that the economic crises in the CBI region would soon lead to additional and serious political instabilities if not corrected.

The legislation passed by Congress is to be in effect until 1996 and is designed to promote economic revitalization in the region by waiving prevailing duties on most products imported into the United

Opinions expressed and conclusions drawn are solely mine. Neither the Office of International Cooperation and Development nor any other agency of the United States Government is responsible in anyway for these remarks. Any errors made are also my responsibility. Thanks to Larry Boone and Richard Brown, Economic Research Service/USDA; Tom King, Rural Development Division/USAID's Bureau for Latin America and the Caribbean; and to three anonymous HortScience reviewers for their valuable suggestions and assistance. L. George Wilson, North Carolina State Univ., gave helpful encouragement and suggestions. Thanks to Allison Farwell, USAID's Bureau for Latin America and the Caribbean, for typing many drafts.

'Present address: Agency for International Development, Washington, DC 20523.
States from these designated beneficiary CBI countries. The basic provisions of the Act (U.S. Congress, 1983) include the following: a) Duty-free imports on eligible articles; b) designation of beneficiary countries; c) list of exempt commodities; d) rule-of-origin requirements; and e) procedures to provide emergency relief from imports.

The Act exempted certain commodities from duty free status. Included were textiles and apparel; footware, handbags, luggage, flat goods, work gloves, and leather wearing apparel; canned tuna; petroleum and petroleum products; watches and watch parts; and limitations on duty-free entry of sugar. In the latter case, the president has imposed sugar quotas based on each country's historical share of the market.

The rule of origin requirement was designed to assure that an article of commerce under the Act is produced in the designated CBI country to qualify for duty-free treatment. The provisions seek to prohibit "pass through" operations and "runaway plants". Dutyfree status may be accorded an article or commodity only if the sum of the cost or value of the material produced in a beneficiary country or countries, plus the direct costs of processing operations, is not $<3570$ of the appraised value of the article at the time it is entered.

Under the import and emergency relief provisions of the Act, a special procedure is established to protect American producers of perishable agricultural products. If they file an import relief petition (with the Dept. of Commerce under the Trade Act of 1974), they may also file a request with the secretary of agriculture for emergency relief. Upon recommendation from the secretary of agricultture, following 14 days of investigation of the extent of injury to American producers, the president can withdraw duty-free treatment. Perishable products are defined in the Act as live plants, most

Table 1. Designated CBI countries, as specified in the Caribbean Basin Economic Recovery Act of Aug. 1983.

\begin{tabular}{ll}
\hline \hline & Potential beneficiary countries \\
\hline Anguilla & British Virgin Islands \\
Antigua and Barbuda & Jamaica \\
The Bahamas & Nicaragua \\
Barbados & Panama \\
Belize & St. Lucia \\
Costa Rica & St. Vincent and the Grenadines \\
Dominica & Suriname \\
Dominican Republic & Trinidad and Tobago \\
El Salvador & Cayman Islands \\
Grenada & Montserrat \\
Guatemala & Netherlands Antilles \\
Guyana & (including Aruba) \\
Haiti & St. Christopher-Nevis \\
Honduras & Turks and Caicos Islands \\
\hline
\end{tabular}

